\title{
SHANK LENGTH: SEGREGATION IN AN UNSELECTED CHARACTER IN INBRED LINES OF FOWLS
}

J. S. S. BLYTH

Poultry Research Centre, Edinburgh 9

Received 6.ii.53

THE 25-year-old flock of Brown Leghorns, maintained at the Poultry Research Centre, has been closed since 193I. Before its division into non-interbreeding lines, the descendants of its foundation birds were intermated in such a way that, with one exception, the pedigree of each line still traces back to individuals from all the five widely differing sources from which it was established. In the $\mathrm{N}$ line one foundation sire is missing. The general purpose line, B, has been selected, as a commercial flock might be, for both egg numbers and egg weight ; all the others have been selected for some particular trait as follows : I, intensity of production ; L, large egg ; S, small egg ; $\mathrm{N}$, tendency to lay through the moulting period ; $\mathrm{R}$, excessive red in the plumage ; and $\mathrm{D}$, small body size. Apart from $\mathrm{R}$, initiated 1939 and derived mainly from $\mathrm{S}$, all have been in existence for more than 16 years.

Shank (tarsometatarsus) length was measured for the first time in September 1952. The observations were made on the pullets then coming into production, and on the yearling hens. They showed that the rank order of the lines was the same for both ages with a slight but consistent tendency for the pullet means to be greater than the yearling ones. The lines fell into two main groups, B, L, and $\mathrm{N}$, with means of $95 \mathrm{~mm}$. and over, and I, S, D, and R, $92 \mathrm{~mm}$. and under. There was no regular association with the degree of inbreeding although it was the longest legged line of each set that was least inbred. Apart from two pairs, $\mathrm{L}$ and $\mathrm{N}$, and $\mathrm{D}$ and $\mathrm{R}$, the means of all the line samples, within ages, differed significantly from one another. When sire groups were considered, however, it was evident that there was a good deal of variation in line B, and that some of them were not statistically distinguishable from $\mathrm{L}$ and $\mathrm{N}$. In contrast, line I was remarkably homogeneous; what little variation there was in shank length was skewly distributed in that the bird frequencies piled up to a mode at the upper end of the distribution. This tendency was recognisable in all the shorter legged lines while in the others it appeared to be more normally distributed. These observations suggested that while, within the two main sets, line differences might be a matter of gene frequencies, some barrier existed beyond which the shorter legged lines could not rise; this might be due to shank 
length genes per se or to physiological limits set by other parts of the body.

An inherent association between skeletal variations and those of body weight is to be expected (Lerner, I946) ; comparison of line means for the latter with those for shank length showed that the lines ranked in the same order for both, only $\mathrm{N}$ having slightly longer shanks than were to be expected from its position in respect of weight. This was of interest in that, until recent years, no general selection for body weight had been made. Weight differences between the lines are of long standing (Blyth, I952) and appear to have been to some extent inherent in the genotypes necessary for the traits under selection. Thus, body weight is positively correlated with egg weight; the small egg size arising in the $\mathrm{S}$ line through selection for it, and in $\mathrm{I}$, through selection for the negatively correlated egg numbers, are likely to have exerted a downward pull on body weight. Again the slight increase in shank length in pullets over yearling hens may be attributable to recent pressure on body weight; this was actually demonstrable in line $\mathrm{B}$ where three of the four cocks used to produce the pullets (from randomly assorted mates) belonged to the two longest shanked sire groups of the previous generation.

In two small samples of interline crosses, mean shank length was comparable with that of the longer legged parental group ; one came from lines widely divergent in egg size, and there the mean difference between reciprocal progenies was suggestive of the presence of a maternal effect.

In conclusion, it may be suggested that the different shank lengths, now characterising the various lines of the flock, result mainly, not from the random segregation of genes in the course of inbreeding, but from some unconscious directional pressure. In the early history of the lines certain bodily characteristics appear to have been associated, inevitably or otherwise, with the traits actually under selection and have become incorporated along with them.

\section{REFERENCES}

BLYTH, J. S. S. I952. The correlation between egg number and egg weight in the fowl : an investigation of its inconstancy. Poult. Sci., 3I, 254-268.

LERNER, I. M. I946. The effect of selection for shank length on sexual maturity and early egg weight of the single comb White Leghorn pullets. Poult. Sci., 25, 204-209. 